\title{
Water Resources Management Using Modeling Tools in Desert Regions: The Azraq Basin, Jordan
}

\author{
M. Shawaqfah, I. Alqdah, and O. K. Nusier
}

\begin{abstract}
This research is aim to investigate holistic management of floodwaters in Jordan to better understand how this natural hazard can instead be viewed as a valuable natural resource. The groundwater resources in the study area are depleted by the domestic usage and irrigation uses. The limited amount of the groundwater in the area is attributed to the limited natural recharge through the wadi bed during the occurrence of floods. HEC-HMS model were used in order to estimate the surface runoff. A groundwater model for the study area was used to evaluate the effect of flood water on groundwater recharge using the existing volcanic cave. The result shows that Beer Al-Hamam cave with a volume of 20,000 $\mathbf{m}^{3}$, when used to store flood water and recharge it for groundwater. The groundwater table will rise (localy) in the range of 0.2 to $.5 \mathrm{~m}$ per year.
\end{abstract}

Index Terms-Flood, groundwater recharge, rainfall runoff modeling, Azraq basin.

\section{INTRODUCTION}

Holistic water resources management is paramount in desert climates. Nowhere is this more apparent than in the country of Jordan - a nation facing sparse water availability and rapid population growth. According to [1] Jordan is one of the ten most water-deprived countries in the world. [1] states that water will be one of the most serious challenges to Jordan's future economic growth as the population is expected to double by 2029. Further, the availability of water is expected to be halved in this same time period as groundwater reserves are depleted. However, addressing Jordan's forecasted water resources shortcomings will require innovation, leadership, and holistic management of this precious resource.

Water resources engineers have traditionally treated floodwaters as hazards to be controlled or eliminated rather than as a potential resource. This is particularly true in small and dry basins with few or no perennial streams. The wadis found in Jordan are no exception to this trend. A wadi is a typically dry streambed that is ephemeral in nature (only carries water after precipitation events). This type of system is commonly referred to as an arroyo or as a wash in the Southwestern USA. These systems are often neglected or degraded and are understudied and thus poorly understood. Although wadis only carry water for a short duration and for a few days out of the year, they are still capable of transporting substantial volumes of water following intense

Manuscript received May 29, 2014; revised August 29, 2014.

Moayyad Shawaqfah is with Al al-Bayt University, Jordan (e-mail: msss72@yahoo.com). desert rains. Studies in New Mexico and California, USA, have shown that groundwater recharge via wadis or arroyos can be an important component of the water budget and can strongly influence flood propagation through a watershed [2]. Still, most of the water is rapidly transported downstream and thus lost from the local system. However, demonstration projects in Egypt, and other desert regions, have shown the potential to capture a portion of this floodwater in order to put it to beneficial use by increasing infiltration or storing the water for later use.

\section{STUDY AREA}

Location - The study area is located in the north-eastern part of Jordan within the Azraq basin (Fig. 1a) between $31^{\circ}$ $51^{\prime} 28^{\prime \prime}$ and $32^{\circ} 34^{\prime} 26^{\prime \prime} \mathrm{N}$ and $36^{\circ} 30^{\prime} 14^{\prime \prime}$ and $37^{\circ} 40^{\prime} 1^{\prime \prime} \mathrm{E}$. The study area selected for this research covers an area of $4,899 \mathrm{~km}^{2}$, which represents $30 \%$ of the Azraq basin area.

Socio-Economic Characteristics - The study area is inhabited by more than 25,000 people who live in 30 towns, villages, and small settlements Fig. 1b [3]. The livestock industry was a major source of income for the local population but this income has declined due to droughts and the high cost of animal feed [4]. Irrigated agriculture in the study area started in the early 1990s after a government decision to allow wells to be dug in order to start cultivating the land in areas close to the Syrian border. Fig. 1b shows the major land uses in the study area. It shows that all agricultural activities are concentrated in the North Western part of the study area, while the remaining area is considered as free rangelands.

Physical Characteristics - The soil in the study area is associated with the North Jordan basalt plateau which includes well developed xerochrepts on older basalt flows, with gypsitic and calctic horizons and weakly developed xerothents on the recent basalt flows and in Wadis [5]. Xeric and Xerochreptic subgroups constitute $80 \%$ of the soils in the area. Clay percentages in the study area vary between 15 to $29 \%$. Soil textures in the study area are loam, sandy loam, silty clay loam, and silty loam (Fig. 1c)

The climate in the study area is generally characterised by its hot dry summers and cold winters. The study area is characterised by low precipitation and high potential evaporation [5]. In the study area, rainfall usually falls in the form of high intensity, short duration and irregular storms [6]. It receives the greatest amount on the highest parts of the study area towards the Syrian border [7]. Fig. 1d shows the rainfall Isohyets in the study area. It shows that most of the study area receives less than $100 \mathrm{~mm} \mathrm{yr}^{-1}$. The estimated 
evapotranspiration can be fifty times greater than the mean annual rainfall [6] averaging $1500 \mathrm{~mm}$ to $2000 \mathrm{~mm}_{\text {year }}{ }^{-1}$ [8]. There is a seasonal variation in temperature in the study area. In summer, mean annual maximum temperatures reach $35^{\circ} \mathrm{C}$ to $38^{\circ} \mathrm{C}$ in August but absolute maxima rarely exceed $40{ }^{\circ} \mathrm{C}$. In winter, the temperature rarely falls below freezing, with annual minimum temperatures as low as $2{ }^{\circ} \mathrm{C}$ to $9{ }^{\circ} \mathrm{C}[5]$ and [9]. The variation in topography within the basalt area results from the different basaltic flows. Each basaltic flow has its own age, physical and mineralogical characteristics. The oldest flows are characterised by being smooth, with well-established drainage patterns and a fine colluvial rill network, while the younger flows tend to have an irregular topography, filled depressions and a crudely connected drainage network. Regions of smoothly rising hills with dark basalt rocks of various sizes cover the desert plain and dominate the topography of the study area [6]. Fig. (1.d) shows the elevation over the study area. There are a number of wadis that flow in the study area (Fig. 1.e). The direction of their flow is towards the south following the gentle north-south slope of the topography [10]. Within the study area there are no natural surface water bodies. Surface waters run through the existing wadis in wet years and drain into the Qa'a Azraq (outside the study area). These wadis have poorly defined drainage patterns, which result from low gradient slopes throughout the study area. However, voluminous wadi runoff in the form of flash flooding is produced due to intense thunderstorms [10].
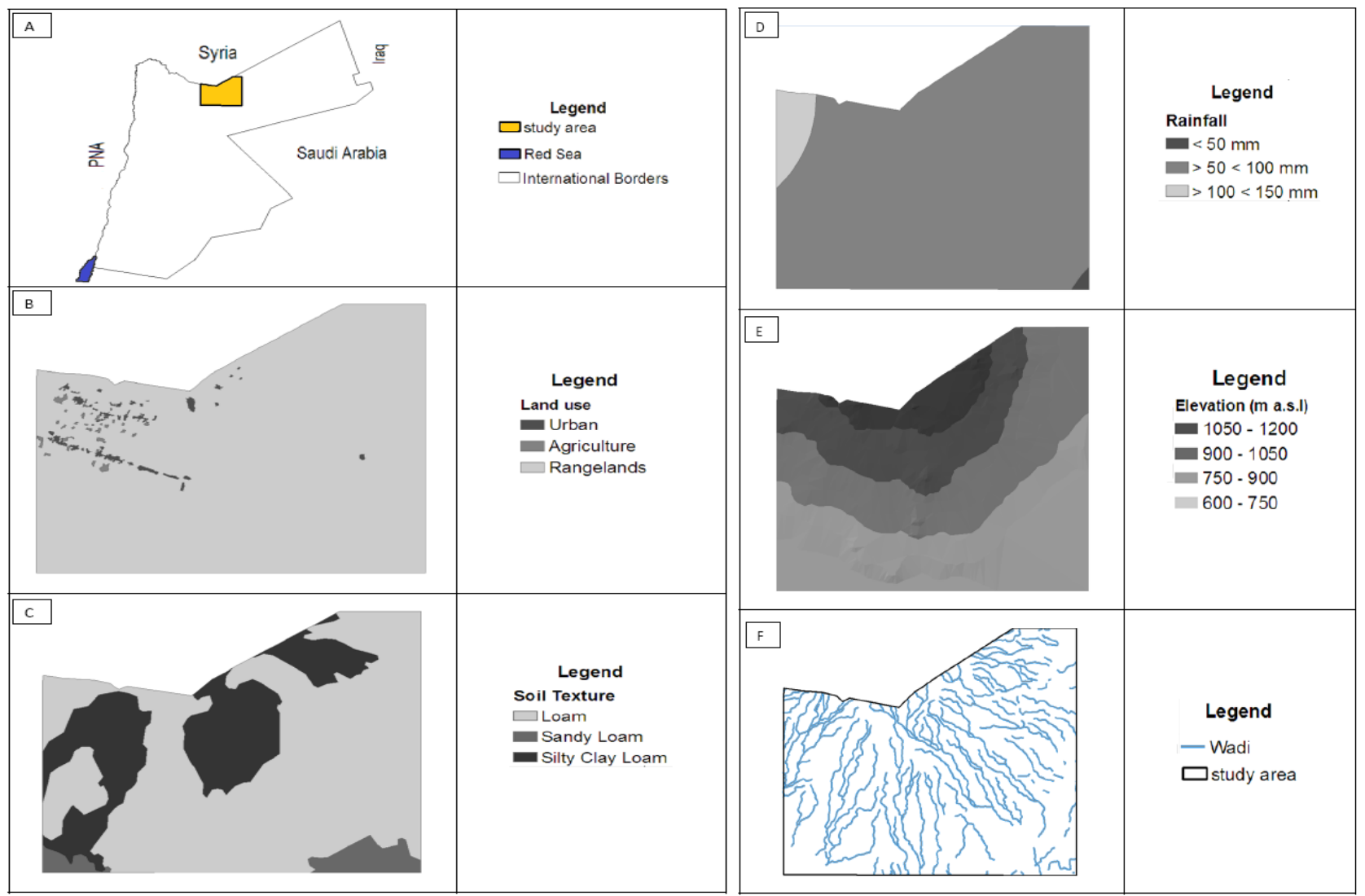

Fig. 1. The Location, physical, and socio-economic characteristics of the study Area.

Groundwater aquifers in Azraq basin can be divided into three main hydraulic complexes [11]:

1) the Shallow Aquifer System (Upper Aquifer, B4/B5+ Basalt); 2) the Upper Cretaceous (Middle Aquifer System, B2/A7) Amman-Wadi Sir Hydraulic Complex; and (3) the Deep Sandstone (Lower Aquifer System), Kurnub and Disi Hydraulic Complex.

The dilemma is that the upper aquifer (study area) is overexploited. The estimated safe yield of the upper aquifer is about $24 \mathrm{MCM}$, and the estimated amount of water extracted from the basin is $55 \mathrm{MCM}$. The situation of the groundwater in this aquifer is deterioration considerably year after year. Volcanic caves are found in several locations along the basalt plateau within the study area. These volcanic caves are distributed over in the basaltic area. Some of them are located inside the wadis, or nearby at short distances from the major wadis, and the others are found on and above the wadis' embankments. This study aims at investigating the possibility of using such volcanic caves to recharge the groundwater.

\section{ModELING}

\section{A. Rainfall-Runoff Models (HEC-HMS Model)}

The climate of the study area is characterized by hot summers and cold winter. The precipitation data for the most recent 20 years period from 1990 to 2010 water years indicate that average annual precipitation in the vicinity of the pilot site and in the upstream basin ranges from approximately 110 to $130 \mathrm{~mm}$. The annual average potential evaporation is approximately $1.07 \mathrm{~mm}$. The real evaporation 
losses are about $90 \%$ of the precipitation, so that only $10 \%$ remain for runoff most of it in connection with flash floods.

In the study area, a hydrologic model was generated to estimate the runoff potential by using the Hydrologic Modeling System of the Hydrologic Engineering Center [12]. The HEC-HMS model provides a variety of options for simulating precipitation-runoff processes.

For HEC-HMS model the following data are used:

The Catchment and its sub-basins parameters such as area, slope and main channel length

The Curve Number method was used to calculate rainfall losses and excess and the SCS (soil conservation service) Unit Hydrograph method to develop the runoff hydrograph.

Design storm depth, where historical daily rainfall data for stations in the study area are used to find the depth of the design daily storm.

For this study, Beer Al-Hamam cave was chosen to determine the effect of flood water in groundwater recharge. It is length about $445 \mathrm{~m}$ and it can store $20,000 \mathrm{~m}^{3}$ of water. The catchment area of the cave is $93.5 \mathrm{Km}^{2}$ as shown in Fig. 2.

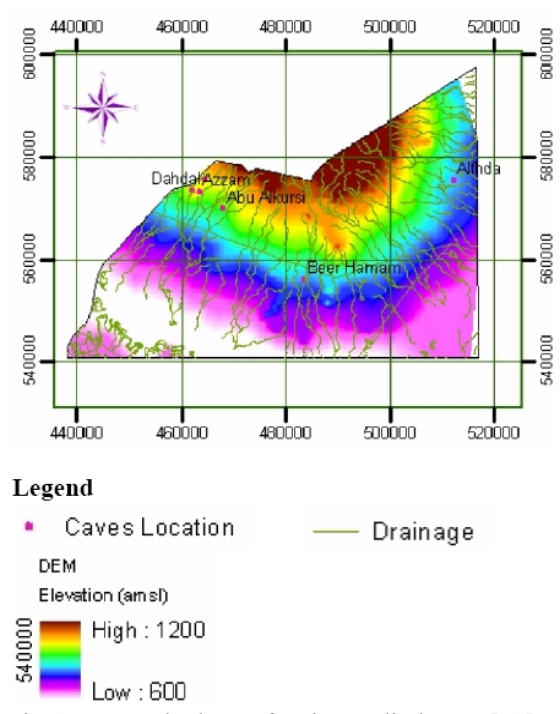

Fig. 2. Watershed area for the studied cave [13].

The National Resources Conservation Services (NRCS) Curve Number (CN) Method is used to calculate rainfall losses and excess rainfall. In this Method, the $\mathrm{CN}$ used is 78 (calculated based on land use and soil type) and the initial abstraction is calculated as $14.3 \mathrm{~mm}$ using the following equations:

$$
\begin{gathered}
S=\frac{25400}{C N}-254 \\
I a=0.2 S
\end{gathered}
$$

where:

$S$ is the potential storage $(\mathrm{mm})$,

$C N$ is the Curve Number,

$I_{a}$ is the initial abstraction ( $\left.\mathrm{mm}\right)$,

The NRCS Unit Hydrograph (UH) method is used to simulate the sub-basins runoff hydrographs and the Catchment's outflow Hydrograph. For this method, the lag time is calculated using the following NRCS (SCS) equation:

$$
t_{c}=0.136 L^{0.8}\left(\frac{1000}{C N}-9\right)^{0.7} S^{-0.5}
$$

$S$ is the Sub-basin slope (\%)

where:

$$
t_{L}=0.6 t_{c}
$$

$t_{c}$ is the time of concentration ( $\mathrm{min}$ ),

$t_{L}$ is the lag time (min),

$L$ is the main wadi length (m),

$C N$ is the Curve Number,

The 24-hrs storm is distributed using National Resources Conservation Services (NRCS) (Formally known as Soil Conservation Service (SCS)) Type II storm was used.

For the years $1990-2010$, the total rainfall for Um Al-Qutain Station was $1647.4 \mathrm{~mm}$. Only 29 storms during this period exceeded the initial abstraction of $14.3 \mathrm{~mm}$ and resulted in. The total rainfall depth for these storms was $689.8 \mathrm{~mm}$ which forms about $41.9 \%$ of the total rainfall in the same period. Each one of these storms is modeled using HEC-HMS.

\section{B. Groundwater Model}

The model domain was selected to cover $4,899 \mathrm{~km}^{2}$ of the total area $\left(16,330 \mathrm{~km}^{2}\right)$ of the Azraq basin. The area of the modeling domain was chosen based on data availability and model boundaries not to be affected by stresses within the modeling domain. The domain is located between 299000 PB-E, 1165000PB-N (left lower corner) and 343000 PB-E, 1205000PB-N (upper right corner) Palestine _ 1923 Palestine_Belt. The model domain was discretized using $8 \overline{0}$ rows $\times 88$ columns square cells. This discretization produces 7040 cells in the model layer. The width of the cells along rows $(\Delta \mathrm{X})$ and along columns $(\Delta \mathrm{Y})$ are constant $(500 \mathrm{~m})$.

Topographical and hydrogeological contour maps obtained from the Ministry of Water and Irrigation were used to determine the top and bottom of the upper aquifer layer for each cell. The upper aquifer system has a wide range of hydraulic conductivities. The measured hydraulic conductivities from the pumping tests provide values ranging from 0.01 to $90 \mathrm{~m} /$ day [14]. Depending on the maps of the groundwater flow pattern of the upper aquifer, and the structural maps, the boundary conditions were identified as shown in Fig. 3. The steady state condition is a condition that existed in the aquifer before any development had occurred. Match the initial heads observed for the aquifer with the hydraulic heads simulated by MODFLOW is called steady state calibration that is done by sequential adjustment of the model parameters. Hydraulic conductivities, those estimated from previous studies and from pumping tests were used as initial values for the steady state simulation. By using the trail and error calibration, the horizontal was adjusted during many sequential model runs until the match between the observed and simulated heads were obtained as shown in Fig. 3. Also, minor adjustments were done on the boundary conditions that are firstly used in the initial runs.

Total runoff depth for the years 1990 - 2010 was 52.71 $\mathrm{mm}$ which forms about $3.2 \%$ of the total rainfall and about $7.6 \%$ of the total storms greater than the initial abstraction. For Beer Al-Hamam catchment that has an area of $93.5 \mathrm{~km}^{2}$, it received about $155.8 \mathrm{Mm}^{3}$ of rainfall during the years 1990 -2010 , only $3.2 \%$ of that was generated as runoff (about 5 $\mathrm{Mm}^{3}$ )

Transient calibration step comes after finishing steady state calibration step, where successful transient calibration 
step depends on the good results obtained from the steady state calibration step, mainly, hydraulic conductivities and boundary conditions. Typically, specific yield for unconfined aquifers and storage coefficient for confined aquifers are the main parameters that are changed during the transient calibration in order to get calibrated model. The year of 1985 was considered as the year in which the transient calibration started for the upper aquifer. Twenty six stress periods were selected to cover the time period of 26 years (1985-2010), where as each stress period consists of 365 days in one time step. The available data from 1985 to 2002 were used for calibration processes and the rest data were used for the validation purposes. The available data of the monitoring wells were used in the calibration process. The calibration was done by changing the specific yield values and then several computer runs were performed until reasonable matches were obtained between the observed and simulated heads. Time dependent model simulations for a time period of years (1985-2002) with well known withdrawal rates have been carried out in order to compare between the observed and calculated head. In addition, further model runs were carried out for hydraulic heads validation for the time period of 9 years based on continuous groundwater withdrawal rates. The average specific yield was about 0.025 .

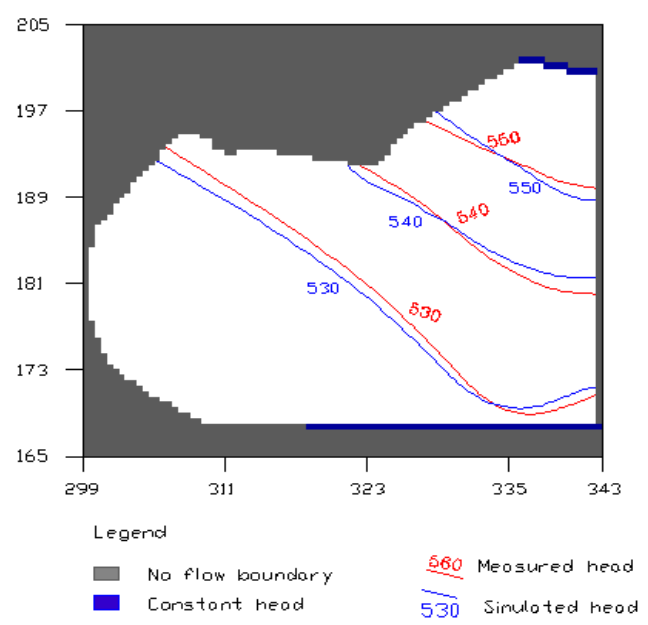

Fig. 3. Map of the measured and simulated water levels for the upper aquifer (Steady state calibration).

\section{Groundwater Recharge}

Groundwater models were developed to predict the effects of groundwater abstraction and analyze the impacts of different groundwater management options on the behavior of the aquifer system. Beer Al-Hamam cave was used to recharge groundwater, and the groundwater model showed small local effect on the water table recovery about (0.2-0.5 $\mathrm{m} /$ year).

\section{CONCLUSION}

The available surface water which is the total runoff in an average year conditions is $290,000 \mathrm{~m}^{3} /$ year. The usage of it is the subject of best management of volcanic caves usage. The possibility of using it for artificial recharge should be considered. The total direct recharge into the upper aquifer system is about $34 \mathrm{MCM} / \mathrm{Y}$.
The upper aquifer system has been fully utilized on more than the safe yield basis. It is believed that any extra amount of withdrawal will have an adverse effect on the environment. The usage of volcanic caves to store flood water and recharge it to groundwater will be a vital solution for groundwater shortage in Jordan.

\section{ACKNOWLEDGEMENTS}

This research was supported by a grant from the PEER Program, (USAID).

\section{REFERENCES}

[1] USAID. (2011, Nov. 27). USAID Jordan Website. [Online]. Available: http://jordan.usaid.gov/index2011.html. Last accessed.

[2] EPA, The Ecological and Hydrological Significance of Ephemeral and Intermittent Streams in the Arid and Semi-arid American Southwest, U.S. Environmental Protection Agency, 2008.

[3] DOS, Jordan Department of Statistics, the Jordan national population censuses for 2010, internal report, Amman, Jordan, 2011.

[4] S. A. Oun, "Demographic and social settings," Living with water scarcity: Water resources in Jordan, Badia Region, and The way forward. Al al- Bayt University, Jordan, vol. 2, 2001.

[5] R. J. Allison, D. L. Higgitt, A. J. Kirk, J. Whrburton, A. S. A. Homoud, B. F. Sunna, and K. White, "Geology, geomorphology, hydrology, groundwater and physical resources," Arid land resources and their management: Jordan's Desert Margin, London, Kegan Paul International, vol. 1, pp. 21-46, 1998.

[6] N. A. Al-Ansari and S. M. J. Baban, The Climate and Water Resources, 2001.

[7] R. J. Allison, N. J. Rosser, J. Whrburton, J. R. Rose, D. L. Higgit, and A. Kirk, "Geomorphology of the eastern Badia basalt plateau, Jordan," Geographical Journal, vol. 166, no. 4, pp. 352-370.

[8] R. W. Dutton and M. Shahbaz, "The Badia Programme: Defining and overcoming constrains on sustainable Development," Applied Geography, vol. 19, pp. 275-281, 1999.

[9] A. Millington, S. A. Hussein, and R. Dutton, "Population Dynamics, socioeconomic change and land colonisation in Northern Jordan, with spatial reference to the Badia Research and Development Project area," Applied Geography, vol. 19, pp. 363-386, 1999.

[10] J. Waddingham, "Water demand in the North-east Badia," M.Sc. thesis, University of Newcastle Upon Tyne, UK, 1994.

[11] A. Hydrotechnik, "National water master plan of Jordan," International Economic Development Program, vol. 8, Essen-Hanover, 1997.

[12] US Army Corps of Engineers, User's Manual. HEC-HMS 3.5, Hydrologic Modeling System, August 2010.

[13] H. A. Amoush, "Integrations of vertical electrical sounding and aeromagnetic data using GIS techniques to assess the potential of unsaturated zone and Volcanic Basaltic Caves for groundwater artificial recharge in NE-Jordan," Jordan Journal of Civil Engineering, vol. 4, no. 4, pp. 389-408, 2010.

[14] MWI. (2008). Ministry of Water and Irrigation of Jordan. [Online]. Available: http://www.mwi.gov.jo.

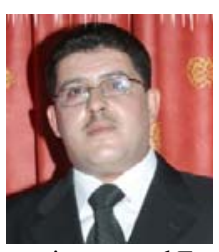

Mo'ayyad Shawaqfah pursued his B.Sc. in civil engineering from Jordan University of Since and Technology (JUST), Jordan, 1994 and his M.Sc degree in water recourses and environmental engineering from Jordan University of Science and Technology in 1997 and his $\mathrm{PhD}$ from Washington State University, USA in 2002 majoring in environmental Engineering. Dr. Shawaqfah is an assistant professor at Al al-Bayt University in the Civil Engineering Department. His research involves developing computational models for groundwater/surface water interactions. Specifically, he has developed numerical models capable of accurately simulating wastewater and freshwater migration through variably saturated soils during groundwater recharge events. He has also developed complex models for predicting the influence of the so-called "Muck Layer". 